\title{
DESIGN, OPTIMISATION AND EVALUATION OF PIROXICAM FAST DISSOLVING TABLETS EMPLOYING STARCH TARTRATE-A NEW SUPERDISINTEGRANT
}

\section{R. SANTOSH KUMAR*, ANKITA GHOSH}

\author{
GITAM Institute of Pharmacy, GITAM Deemed to be University, Rushikonda, Visakhapatnam, A. P 530045, India
}

Email: drsantoshrada@gmail.com

Received: 24 Sep 2018, Revised and Accepted: 05 Mar 2019

\section{ABSTRACT}

Objective: To enhance the solubility of poorly soluble drugs by evaluating starch tartrate as a superdisintegrant in the formulation of fast dissolving tablets by employing $2^{3}$ factorial design.

Methods: Starch tartrate was synthesized by gelatinization process. The physical and micromeritic properties were performed to evaluate the synthesized starch tartrate. The fast dissolving tablets of piroxicam were prepared by using starch tartrate as a superdisintegrant in different proportions by direct compression technique using $2^{3}$ factorial design. The drug content, hardness, friability, disintegration time and other dissolution characteristics like percent dissolved in 5 min ( $\left.\mathrm{PD}_{5}\right)$, dissolution efficiency in 5 min (DE ${ }_{5}$ ) and first-order rate constant ( $\mathrm{K}_{1}$ ) were used in the evaluation of prepared fast dissolving tablets.

Results: The superdisintegrant starch tartrate prepared was found to be fine, free-flowing slightly crystalline powder. Starch tartrate exhibited good swelling in water. The study between piroxicam and starch tartrate was shown the absence of interaction by fourier transform infrared spectra (FTIR) and differential scanning calorimetry (DSC). The drug content (99.83 $\pm 0.56 \%)$, hardness (3.7-3.9 kg/sq. Cm), and friability (0.12$0.15 \%)$ have been effective with regard to all the formulated fast dissolving tablets employing starch tartrate. The disintegration time of all the formulated fast dissolving tablets (FDTs) was found to be in the range of $12 \pm 0.01$ to $4500 \pm 0.02$ s. The optimized formulation F6 has the least disintegration time i.e., $12 \pm 0.01 \mathrm{~s}$. The In vitro wetting time of the formulated tablets was found to be in the range of $35 \pm 0.09$ to $1624 \pm 0.02 \mathrm{~s}$. The InVitro wetting time was less (i.e., 90s) in optimized formulation F6. The water absorption ratio of the formulated tablets was found to be in the range of $60 \pm 0.12$ to $65 \pm 0.15 \%$. The cumulative drug dissolved in the optimized formulation F6 was found to be $99.32 \pm 0.09 \%$ in 10 min

Conclusion: The dissolution efficiency of piroxicam was enhanced when starch tartrate was found to be a superdisintegrant when combined with crospovidone and, hence it could be used in the formulation of fast dissolving tablets to provide immediate release of the contained drug within 10 min.

Keywords: Fast dissolving, Superdisintegrant, Starch tartrate, Dissolution efficiency

(C) 2019 The Authors. Published by Innovare Academic Sciences Pvt Ltd. This is an open access article under the CC BY license (http://creativecommons.org/licenses/by/4.0/] DOI: http://dx.doi.org/10.22159/ijap.2019v11i3.29935

\section{INTRODUCTION}

Drug delivery systems are tools for expanding markets, extending product life cycles and generating opportunities. Oral administration is the most common route for systemic action due to easy ingestion, pain, avoidance, versatility and patient compliance. Parentrals are generally not preferred by patients. The preference for solid dosage forms that can be dissolved and suspended in water, chewed, or rapidly dissolved in the mouth is particularly more in the pediatric and geriatric patients, with further application to other patients who prefer an easily administered dosage form.

Because of the increase in the average human lifespan and the decline of swallowing ability with age, oral administration of dosage forms to patients is a significant problem and has become the object of public attention. The problem can be resolved by developing rapidly dispersing or dissolving oral forms, which does not require water for swallowing. The dosage forms are allowed to disperse or dissolve in the saliva when placed in the mouth and then are swallowed normally. The bioavailability of a drug from fast dissolving formulations may be even greater than standard dosage forms. In some cases, problems related to motion sickness, sudden allergic attacks and unavailability of water to swallow conventional tablets can be resolved by use of fast disintegrating tablets. When placed on the tongue, this tablet disintegrates immediately, releases the drug, which dissolves in the saliva.

The present investigation involved in the preparation and evaluation of starch tartrate as superdisintegrant in the formulation of fast dissolving tablets of poorly soluble drugs like piroxicam. Therefore the solubility and dissolution rate of piroxicam can be enhanced resulting in greater bioavailability of drugs [1-5].

\section{MATERIALS AND METHODS}

\section{Materials}

Sodium hydroxide, tartaric acid, carbon disulfide, mannitol was purchased from Finar chemicals Ltd, Ahmedabad. Potato starch, piroxicam, crospovidone, croscarmellose sodium was obtained from Yarrow chem. products, Mumbai. Microcrystalline cellulose was bought from Qualigens fine chemicals, Mumbai. Talc and magnesium stearate was obtained from Molychem, Mumbai.

\section{Preparation of starch tartrate (a novel superdisintegrant)}

Initially, 10 parts of tartaric acid were dissolved in $25 \mathrm{ml}$ of distilled water. The $\mathrm{pH}$ of the dispersion was checked. If $\mathrm{pH}$ was not 3.5 , the 10 (M) sodium hydroxide solution was added to adjust to $\mathrm{pH} 3.5$. This dispersion was conditioned for $16 \mathrm{~h}$. After $16 \mathrm{~h}$ it was dried in the oven at $60{ }^{\circ} \mathrm{C}$ until it gets dried. The mass was washed with distilled water to remove the unreacted tartaric acid. The product was kept in the oven at $60{ }^{\circ} \mathrm{C}$ until it gets dried. The product obtained was ground and sieved (\# 80).

\section{Characterization of starch tartrate}

The starch tartrate prepared was evaluated for the following

\section{Solubility}

The solubility of starch tartrate was tested in distilled water, an aqueous buffer of $\mathrm{pH} 1,2,3,4,5,6$, and 7.4 and organic solvents such as alcohol, dichloromethane, chloroform, acetone and petroleum ether [6].

pH

The $\mathrm{pH}$ of $6 \% \mathrm{w} / \mathrm{v}$ slurry was measured by $\mathrm{pH}$ meter [6]. 


\section{Melting point}

Melting point was determined by using melting point apparatus [6]

\section{Viscosity}

The viscosity of $1 \%$ dispersion in water was measured using Ostwald Viscometer [6].

\section{Swelling index}

Starch tartrate $(200 \mathrm{mg})$ was added to $10 \mathrm{ml}$ of water and light liquid paraffin was taken in two different measuring cylinders and mixed. The dispersion in the tubes was allowed to stand for $12 \mathrm{~h}$. The volumes of the sediment in the cylinders were recorded. The swelling index of the material was calculated as follows [7]

$S . I(\%)=\frac{\text { Volume of sediment in water }- \text { Volume of sediment in light liquid paraffin }}{\text { Volume of sediment in light liquid paraffin }} \times 100$

\section{Test for gelling property}

The gelling property (gelatinization) of the starch and prepared starch tartrate, was evaluated by heating a $7 \% \mathrm{w} / \mathrm{v}$ dispersion of each in water at $100^{\circ} \mathrm{C}$ for $30 \mathrm{~min}$ [7]

\section{Particle size}

Particle size analysis was done by sieving using standard sieves [7].

\section{Density}

Density (g/cc) was determined by liquid displacement method using benzene as liquid [7].

\section{Bulk density}

Both loose bulk density (LBD) and tapped bulk density (TBD) were determined by transferring the accurately weighed amount of sample in $50 \mathrm{ml}$ measuring cylinder, and tapped 50 times on a plane surface and tapped volume of packing recorded and LBD and TBD calculated by the following formula [8].

$$
\begin{gathered}
\mathrm{LBD}=\frac{\text { Mass of powder }}{\text { volume of packing }} \\
\mathrm{TBD}=\frac{\text { Mass of powder }}{\text { Tapped volume of packing }}
\end{gathered}
$$

\section{Percentage compressibility index}

Percentage compressibility of the powder mix was determined by Carr's Compressibility Index calculated by the following formula [9].

$$
\% \text { Carr"s Index }=\frac{(\mathrm{TBD}-\mathrm{LBD})}{\mathrm{TBD}} \times 100
$$

Where TBD= Tapped bulk density; $\mathrm{LBD}=$ Loose bulk density.

\section{Angle of repose}

The frictional forces in loose powder or granules can be measured by the angle of repose. This is the maximum angle possible between the surface of a mass of powder and the horizontal plane. The angle of repose is calculated by applying the next equation [9];

$$
\tan \theta=\frac{h}{\mathrm{r}} \quad \theta=\tan ^{-1} \frac{\mathrm{h}}{\mathrm{r}}
$$

Where $\theta=$ angle of repose; $h=$ height of the pile of powder; $r=$ radius of the pile of powder

\section{Fourier transform infrared (FTIR) spectroscopy}

FTIR spectra of starch tartrate were recorded on samples prepared in potassium bromide $(\mathrm{KBr})$ disks using a BRUKER FT-IR,(Tokyo, Japan). The scanning range was 500 to $4000 \mathrm{~cm}^{-1}$. Samples were mixed with $(\mathrm{KBr})$ to form disks by means of a hydrostatic press at 6 8 tons pressure [8].

\section{X-Ray diffraction}

The diffraction pattern of starch tartrate was recorded with an x-ray diffractometer (analytical spectra's Pvt. Ltd., Singapore). X-ray diffraction was performed at room temperature $\left(30^{\circ} \mathrm{C}\right)$ with a diffractometer; target, $\mathrm{Cu}(\lambda 1.54 \mathrm{~A})$, filter, $\mathrm{Ni}$; voltage, $40 \mathrm{kV}$; current $30 \mathrm{~mA}$; time constant $10 \mathrm{~mm} / \mathrm{s}$; scanning rate $2 \%$ min; measured from $10-35^{\circ}$ at full scale 200 [8].

\section{Drug-excipients compatibility studies}

The compatibility of starch tartrate with the selected drug (piroxicam) was evaluated in DSC and FTIR studies.

\section{Differential scanning calorimetry (DSC)}

DSC thermograms of piroxicam and their mixtures (1: 1) with starch tartrate were recorded on Perkin Elmer thermal analyzer samples (2-5 $\mathrm{mg})$ were sealed into aluminum pans and scanned at a heating rate of $10^{\circ} \mathrm{C} \mathrm{min}-1$ over a temperature range $30-350{ }^{\circ} \mathrm{C}[8]$.

\section{Infrared spectroscopy}

Fourier transform infrared (FTIR) spectra of piroxicam and their mixtures (1: 1) with starch tartrate were recorded on a Perkin Elmer, IR Spectrophotometer model: Spectrum RXI, using $\mathrm{KBr}$ disc as reference $[8,9]$.

\section{Preparation of piroxicam fast dissolving tablets}

The tablets were prepared by direct compression technique using $2^{3}$ factorial design in which 3 independent variables \{superdisintegrants i.e., starch tartrate (A), crospovidone (B), croscarmellose sodium (C)\} and 1 dependent variable (dissolution efficiency in $5 \mathrm{~min}$ ) were taken into consideration. The composition of the different formulation of piroxicam fast dissolving tablets is shown in table no 1 in which the levels of superdisintegrants were selected at 2 levels i.e., lower and higher level concentrations. For starch tartrate (A), the lower level i.e. $0 \%$ concentration and upper level i.e. 5\% concentration. For crospovidone (B) and croscarmellose sodium(C) also, the lower level is $0 \%$ concentration and higher level i.e., $5 \%$ concentration. For uniformity in particle size, each ingredient was passed through \# 100 mesh sized screen before mixing. Starch tartrate, crospovidone, croscarmellose sodium, mannitol, and microcrystalline cellulose were accurately weighed, transferred and mixed using a mortar and pestle, and then added to piroxicam. Finally, talc and magnesium stearate were added to the powder mixture. Finally, the mixed blend was

\begin{tabular}{|c|c|c|c|c|c|c|c|c|}
\hline Ingredients & F1 & F2 & F3 & F4 & F5 & F6 & F7 & F8 \\
\hline Piroxicam & 20 & 20 & 20 & 20 & 20 & 20 & 20 & 20 \\
\hline Starch Tartrate & - & 10 & - & 10 & - & 10 & - & 10 \\
\hline Crosscarmellose & - & - & 10 & 10 & - & - & 10 & 10 \\
\hline Crospovidone & - & - & - & - & 10 & 10 & 10 & 10 \\
\hline Mannitol72 & & 62 & 62 & 52 & 62 & 52 & 52 & 42 \\
\hline Micro crystalline cellulose & 100 & 100 & 100 & 100 & 100 & 100 & 100 & 100 \\
\hline Talc & 4 & 4 & 4 & 4 & 4 & 4 & 4 & 4 \\
\hline Magnesium state & 4 & 4 & 4 & 4 & 4 & 4 & 4 & 4 \\
\hline Total & 200 & 200 & 200 & 200 & 200 & 200 & 200 & 200 \\
\hline
\end{tabular}
compressed by using eight station rotator press Karnawathi Machineries Pvt, Ltd., Ahmedabad, India)

Table 1: Formulae of piroxicam fast dissolving tablets employing starch tartrate 


\section{Evaluation of piroxicam fast dissolving tablets}

\section{Hardness test}

Hardness indicates the ability of a tablet to withstand mechanical shocks while handling. By using Monsanto hardness tester, the hardness of tablets was determined and expressed in $\mathrm{kg} / \mathrm{cm}^{2}$ [9]

\section{Uniformity of weight}

Weight variation test was done with 20 tablets. It is the individual variation of the tablet weighed from the average weight of 20 tablets [10].

\section{Friability}

The friability of tablets was measured using a Roche fribilator. Tablets were rotated at $25 \mathrm{rpm}$ for 4 min or up to 100 revolutions. The tablets were reweighed after removing all the fines and the percentage of weight loss was calculated [10].

$$
\mathrm{F}=\frac{100 \mathrm{xW} \text { (initial) }-\mathrm{W}(\mathrm{final})}{\mathrm{W} \text { (initial) }}
$$

\section{Drug content uniformity}

For content uniformity, ten tablets were weighed and powdered. A quantity of powder equivalent to $10 \mathrm{mg}$ of piroxicam was extracted into 7.2 phosphate buffer and filtered. The piroxicam content was determined by measuring the absorbance spectrophotometrically at 221 $\mathrm{nm}$ after appropriate dilution with 7.2 phosphate buffer. The drug content was calculated as an average of three determinations [11].

\section{Wetting time}

The wetting time of tablets was measured by placing five circular tissue papers in a petri dish of $10 \mathrm{~cm}$ in diameter. $10 \mathrm{ml}$ of water containing a water-soluble dye (amaranth) was added to the petri dish. A tablet was carefully placed on the tissue paper. The time required for water to reach the upper surface of the tablet was noted as wetting time $[12,13]$

\section{Water absorption ratio}

A piece of tissue paper folded was kept in a small petri dish to which $6 \mathrm{ml}$ of water was added. A tablet was kept on the tissue paper and allowed to completely wet. The wetted tablet was then weighed. Water absorption ration $\mathrm{R}$ was determined using the following equation $[12,13]$.

$$
R=\frac{100\left(\mathrm{~W}_{1}-\mathrm{W}_{2}\right)}{W_{2}}
$$

Where,

$\mathrm{W}_{1}=$ weight of tablet after water absorption.
$\mathrm{W}_{2}$ = weight of tablet before water absorption.

\section{In-vitro disintegration time}

Disintegration time for FDTs was determined using USP disintegration apparatus $0.1 \mathrm{~N} \mathrm{HCl}$ buffer. The volume of medium was $900 \mathrm{ml}$ and the temperature was $37 \pm 0.2{ }^{\circ} \mathrm{C}$. The time taken for complete disintegration of the tablet was measured [14].

\section{In-vitro dissolution studies}

The in vitro dissolution rate study of piroxicam fast dissolving tablets were performed using 8 stage dissolution test apparatus (Electrolab TDT-08L) fitted with paddles $(50 \mathrm{rpm})$ at $37 \pm 0.5{ }^{\circ} \mathrm{C}$, using 7.2 phosphate buffer $(900 \mathrm{ml})$ as a dissolution media. At the predetermined time intervals, $5 \mathrm{ml}$ samples were withdrawn, filtered through $0.45 \mu$ membrane filter, diluted and assayed at 221 $\mathrm{nm}$ using an Analytical technology T360 UV/Visible Double beam spectrophotometer. Cumulative percentage release was calculated using standard absorbance from the calibration curve. All the dissolution experiments were conducted in triplicate $(n=3)$.

\section{RESULTS AND DISCUSSION}

The starch tartrate prepared was found to be fine, free-flowing slightly crystalline powder. The physical and micromeritics properties of the starch tartrate are summarized in table 2 . It was insoluble in aqueous solvents and insoluble in organic solvents tested (methanol, petroleum ether, dichloromethane, and chloroform) the $\mathrm{pH}$ of $0.1 \%$ aqueous dispersion was 3.85 .

Starch tartrate exhibited good swelling in water. The swelling index was found to be $100 \%$ indicating that it is suitable for superdisintegrant. All micrometric properties indicated good flow properties needed manufacturing of tablets. The density of starch tartrate was found to be $0.625 \mathrm{~g} / \mathrm{cc}$. The angle of repose and compressibility index showed good flow properties of starch tartrate. The FTIR spectrum of potato starch and starch tartrate is shown in fig. 1 and 2. The presence of peaks absorption at 1736.63 $\mathrm{cm}-1$ characteristic peaks of ester, so from FTIR studies it was concluded that starch tartrate (ester) was formed when starch was allowed to react with tartaric acid. The X-ray diffraction pattern (fig. 3) of starch tartrate showed characteristic peaks, which indicates that the structure is slightly crystalline. The disappearance of pink color in the ester test confirmed the presence of ester, i.e., starch tartrate. As the starch tartrate was slightly crystalline powder and it had got all the characteristic of superdisintegrants it was concluded that starch tartrate can be used as novel superdisintegrant in the formulation of fast dissolving tablets.

Table 2: Physical and micromeritics properties of the starch tartrate prepared

\begin{tabular}{ll}
\hline Parameters & Observation \\
\hline Solubility & Insoluble in all aqueous and organic solvents tested \\
pH(1\% w/v aqueous dispersion) & $3.85 \pm 0.01$ \\
Melting Point $\left({ }^{\circ} \mathrm{C}\right)$ & $270 \pm 0.02$ \\
Viscosity $(1 \% \mathrm{w} / \mathrm{v}$ aqueous dispersion in cps) & $1.1034 \pm 0.001$ \\
Swelling index $(\%)$ & $66.5 \pm 0.05$ \\
Gelling property & No gelling at $100{ }^{\circ} \mathrm{C}$ but formed a clear solution. Whereas in the case of starch, it was gelatinized \\
& and formed a gel. \\
Particle Size $(\mu \mathrm{m})$ & $142 \pm 0.02$ \\
Density $(\mathrm{g} / \mathrm{cc})$ & $0.625 \pm 0.001$ \\
Bulk Density $(\mathrm{g} / \mathrm{cc})$ & $0.714 \pm 0.003$ \\
Angle of Repose $\left({ }^{\circ}\right)$ & $23.6 \pm 0.02$ \\
Compressibility Index $(\%)$ & $13 \pm 0.05$ \\
\hline
\end{tabular}

*SD Standard Deviation from mean, $\mathrm{n}=3$

The compatibility of starch tartrate with the selected drug (piroxicam) was evaluated by DSC, FTIR studies. The DSC thermograms of piroxicam and piroxicam-starch tartrate are shown in fig. 5.2 and 5.3. The DSC thermograms of piroxicam and piroxicam-starch tartrate exhibited exothermic peaks at $203.17^{\circ} \mathrm{C}$ and $198.99^{\circ} \mathrm{C}$ respectively. These melting peaks of piroxicam and piroxicam-starch tartrate correspond to the melting points of piroxicam $\left(198-200{ }^{\circ} \mathrm{C}\right)$. The peaks observed in the DSC thermograms of piroxicam and piroxicam-starch tartrate mixtures correspond to the melting points of the respective drug indicating no interactions between the selected drug and starch tartrate polymer. The DSC study, thus, indicated no interaction between starch tartrate and selected drug. 


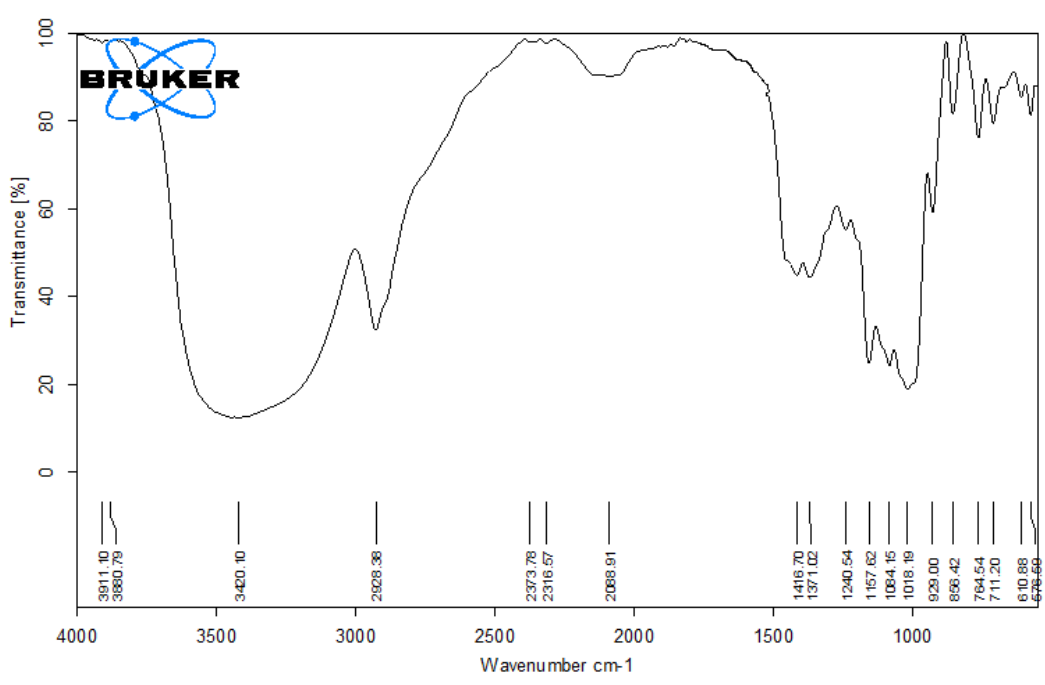

Fig. 1: Fourier transform infrared spectra of potato starch

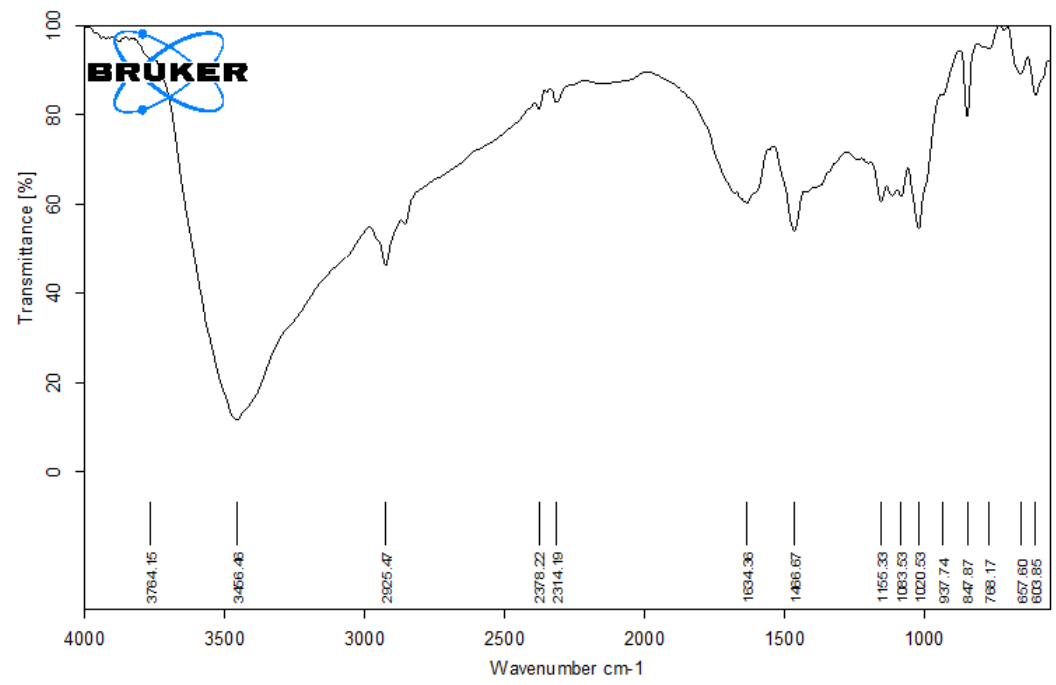

Fig. 2: Fourier transform infrared spectra of starch tartrate

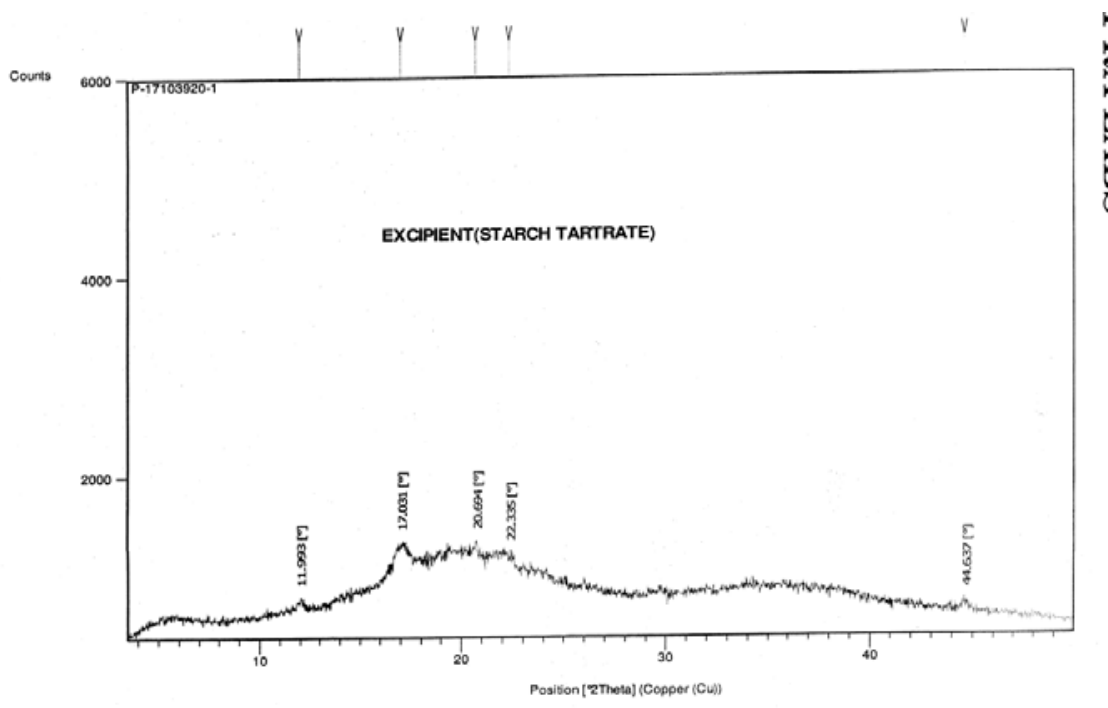

Fig. 3: X-Ray diffraction pattern of starch tartrate 


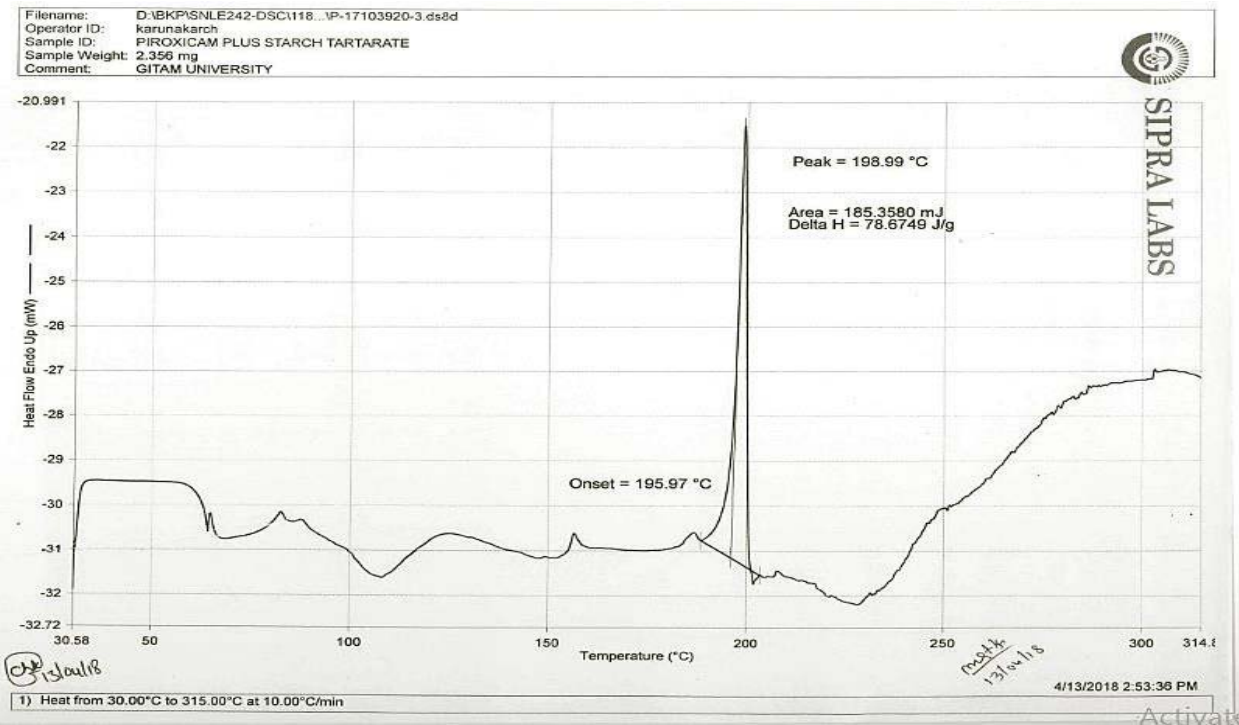

Fig. 4: DSC thermogram of piroxicam pure drug

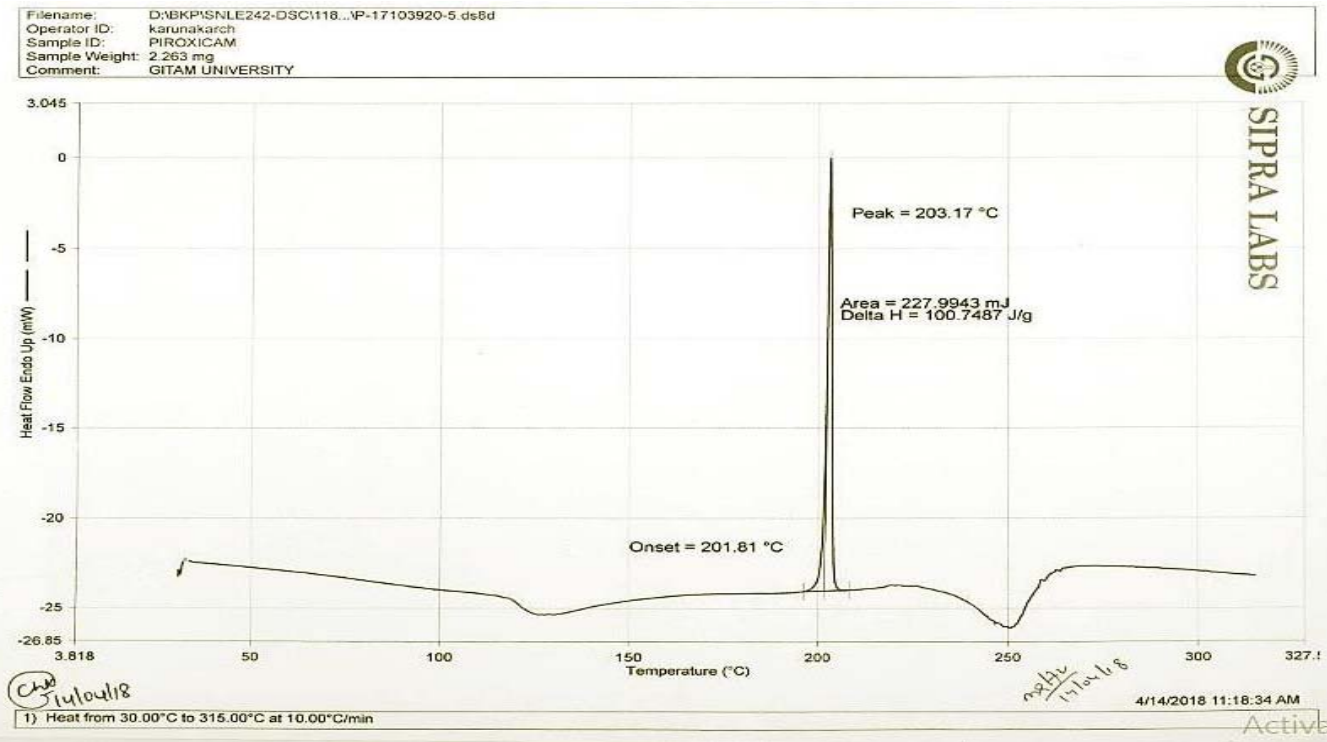

Fig. 5: DSC thermogram of piroxicam with starch tartrate

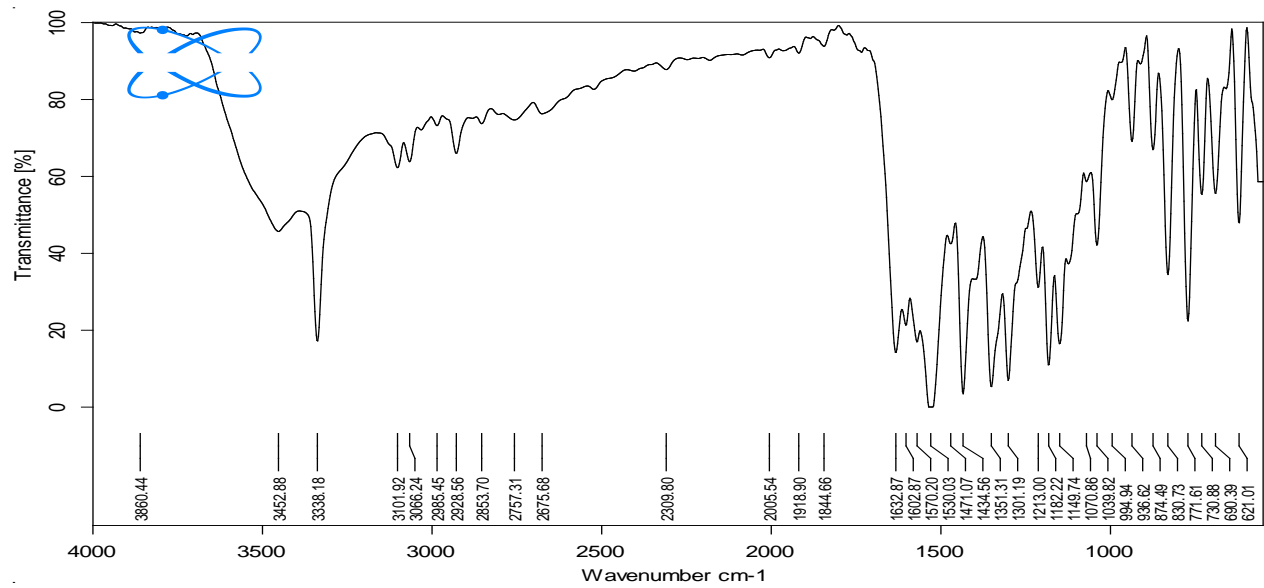

Fig. 6: FTIR spectra of piroxicam 


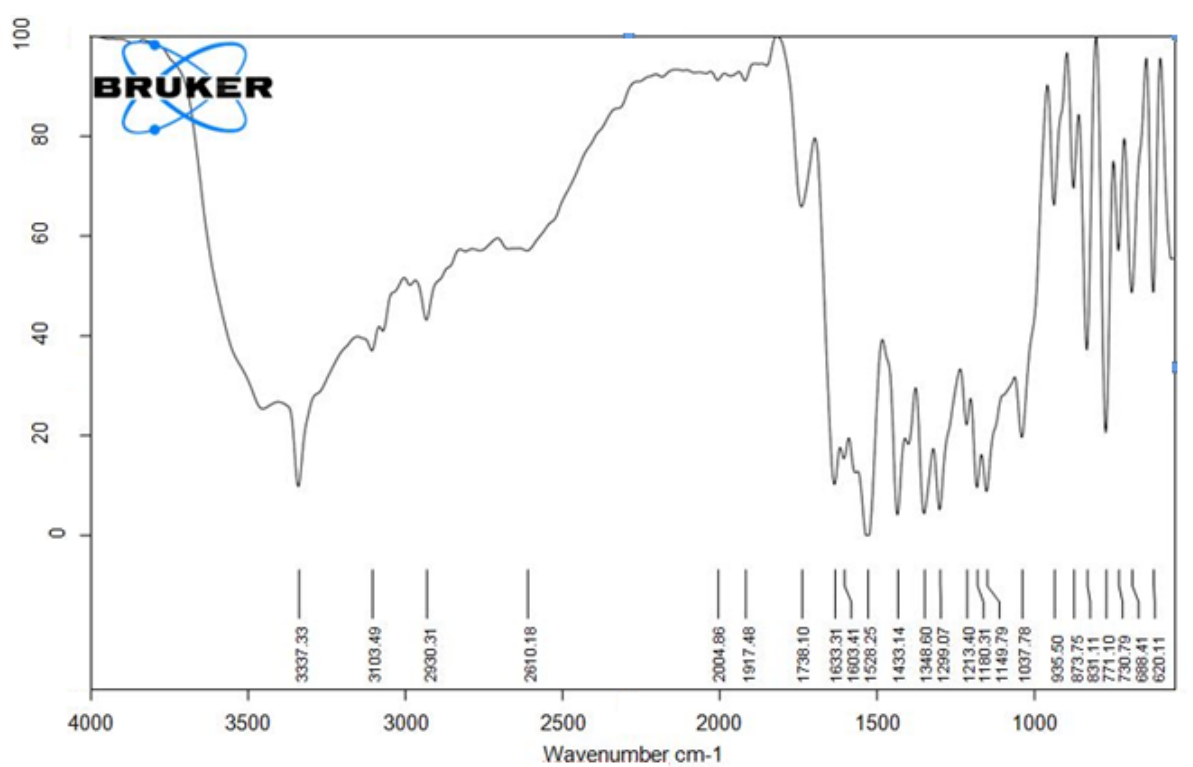

Fig. 7: FTIR spectra of piroxicam with starch tartrate

The FTIR spectra of piroxicam and piroxicam-starch tartrate are shown in Figs.5.4 and5.5. The characteristic FTIR bands of piroxicam at 3338.18 cm-1 (NH), $1632.87 \mathrm{~cm}-1(\mathrm{C}=0), 1434.56 \mathrm{~cm}-1(\mathrm{CN})$ and piroxicamstarch tartrate at $3337.33 \mathrm{~cm}-1(\mathrm{NH}), 1633.31 \mathrm{~cm}-1(\mathrm{C}=0), 1433.14 \mathrm{~cm}$ $1(\mathrm{CN})$ were all observed in the FTIR spectra of both piroxicam and piroxicam-starch tartrate. These FTIR spectra observations also indicated no interaction between starch tartrate and the drug selected.

Thus the results of DSC and FTIR indicated no interaction between the selected drug and starch tartrate, the new superdisintegrant. Hence starch tartrate could be used as a superdisintegrant in the design of fast dissolving tablets of the selected drug.

\section{Evaluation of tablets}

\section{Hardness}

The hardness of tablets from all batches was found to be in the range of $3.6-4 \mathrm{~kg} / \mathrm{sq}$. $\mathrm{cm}$. All tablets were found hard enough so that they could easily withstand the handling and storage conditions without getting broken.

\section{Friability}

The percent friability of all batches found less than $0.15 \%$ indicating the good mechanical resistance of tablets. Thus, it was proved that tablets could withstand the pressure, mechanical shocks during handling, transportation, storage, and manufacturing processes.

\section{Drug content}

Drug content of all the formulation batches was found to be $100 \pm 5 \%$. Hence, it can be concluded that all the formulations are having an accurate amount of drug distributed uniformly in powder mass and followed acceptable limits as per IP [15]. i.e. 85 to $115 \%$ of average content table 3 .

\section{Disintegration studies}

In vitro disintegration time was done by the USP dissolution apparatus. The disintegration rate has a correlation with water absorption. The In vitro disintegration time was found between $12 \pm 0.02$ to $4500 \pm 0.02$ seconds. The outcomes were tabulated and data demonstrated in table 3 . All the formulation showed disintegration time of less than $180 \mathrm{~s}$. It was found that the formulation $\mathrm{F} 6$ will show least disintegration time 12s as compared to other formulation. The order for a disintegration time in fast dissolving tablet was found to be $\mathrm{F} 6<\mathrm{F} 5<\mathrm{F} 7<\mathrm{F} 8<\mathrm{F} 3<\mathrm{F} 4<\mathrm{F} 2<\mathrm{F} 1$. The order of disintegration time may be due to the interaction and main effects of the super disintegrants used in the fast dissolving tablets.

\section{Water absorption ratio and wetting time}

The water absorption ratio founded between $38.5 \pm 0.12 \%-65.2 \pm 0.15 \%$. The increase in behavior due to the water uptake ability of super disintegrants, the wetting time was found between $35 \pm 0.0-1624.2 \pm 0.02$ seconds. The outcomes were tabulated and data demonstrated in table 3 and fig. 8 and 8a. It was found that the formulation F6 containing $10 \%$ starch tartrate and $10 \%$ crospovidone showed less wetting time i.e. as $35 \pm 0.09$ seconds compared to other formulations.

\section{In vitro dissolution studies}

Dissolution rate depends on the wetting time of the disintegrant, among all the formulations F6 has less wetting time and has greater dissolution rate and then this is the other conformance test for correct selection of desirable. In vitro dissolution studies of all the formulation were done and depicted in fig. 9. In all formulations, F6 formulation was selected as the promising formulation containing 5 $\%$ starch tartrate and $5 \%$ crospovidone with $99.32 \% \pm 0.05$ release in 5 min which may be due to the interaction effect between the two super disintegrants i.e., starch tartrate and crospovidone at a concentration of $5 \%$ each.

The dissolution parameters of the formulation from (F1-F8) which were made by direct compression method were shown in the table 4. In all these cases the $\mathrm{PD}_{5}$ (percent dissolved in $5 \mathrm{~min}$ ) was more in F6 which consists at 5\% starch tartrate, and 5\% crospovidone. The same was in the case of $\mathrm{DE}_{5} \%$ (dissolution efficiency in $5 \mathrm{~min}$ ). The $\mathrm{PD}_{5}$ and $\mathrm{DE}_{5} \%$ revels that starch tartrate was effective at $5 \%$ along with $5 \%$ crospovidone when the formulations were made by direct compression using these superdisintegrants. The $\mathrm{K}_{1}$ decreased in all the formulation when compared to $\mathrm{F} 1$ formulation which was given in table 4 . The number of folds increases in $\mathrm{DE}_{5} \%$ and the number of folds increase in $\mathrm{K}_{1}\left(\mathrm{~min}^{-1}\right)$ were given to the table 4 . From the results, it was concluded that starch tartrate (new superdisintegrant) could be used as a superdisintegrant in the formulation of fast dissolving tablets of piroxicam. To evaluate the individual and combined effects of the three factors involved, fast dissolving tablets were formulated employing selected combinations of the factors as per $2^{3}$-factorial design. The fast dissolving tablets and release parameters (percent drug released in $5 \mathrm{~min}$ ) of the fast dissolving formulated were analyzed as per ANOVA of $2^{3}$-factorial design. ANOVA of disintegrating times and dissolution efficiency in 5 min (table 5 and 6) indicated that the individual effects of starch tartrate (A), sodium starch glycolate (B) and crospovidone (C), as well as the combined effects of $\mathrm{AB}, \mathrm{AC}, \mathrm{BC}$ and $\mathrm{ABC}$ factors, were significant $(\mathrm{P}<0.05)$ on disintegration time and dissolution efficiency in 5 min of piroxicam fast dissolving tablets. 
Fast dissolving tablets formulated employing starch tartrate $(5 \%)$, sodium starch glycolate $(5 \%)$ and crospovidone $(5 \%)$ as superdisintegrants exhibited good disintegration and dissolution efficiency in $5 \mathrm{~min}$. Formulation F6 gave release of $99.32 \% \pm 0.05$ in $10 \mathrm{~min}$ fulfilling the official specification, based on disintegration time and dissolution efficiency in $10 \mathrm{~min}$. Formulation F6 is considered as a good fast dissolving tablet formulation of piroxicam which was found to better than the piroxicam fast dissolving tablets formulated by Sachan Anupam et al. [15].

Table 3: Physical properties: hardness, friability drug content of piroxicam fast dissolving tablets.

\begin{tabular}{lllll}
\hline Formulation & $\begin{array}{l}\text { Hardness }\left(\mathbf{k g} / \mathbf{c m}^{2}\right) \\
\mathbf{n} \pm \text { SD }\end{array}$ & $\begin{array}{l}\text { Friability (\%) } \\
\mathbf{n} \pm \text { SD }\end{array}$ & $\begin{array}{l}\text { Drug Content } \mathbf{( m g} / \mathbf{t a b}) \\
\mathbf{n} \pm \text { SD }\end{array}$ & $\begin{array}{l}\text { Disintegration Time (sec) } \\
\mathbf{n} \pm \text { SD }\end{array}$ \\
\hline F1 & $3.7 \pm 0.01$ & $0.12 \pm 0.013$ & $97.58 \pm 0.71$ & $\begin{array}{l}\text { Water Absorption Ratio (\%) } \\
\mathbf{n} \pm \text { SD }\end{array}$ \\
F2 & $3.7 \pm 0.03$ & $0.13 \pm 0.015$ & $98.1 \pm 0.79$ & $4500 \pm 0.02$ \\
F3 & $3.7 \pm 0.01$ & $0.14 \pm 0.012$ & $99.45 \pm 0.63$ & $309 \pm 0.03$ \\
F4 & $3.7 \pm 0.04$ & $0.12 \pm 0.014$ & $98.56 \pm 0.55$ & $72 \pm 0.02$ \\
F5 & $3.8 \pm 0.03$ & $0.14 \pm 0.012$ & $99.83 \pm 0.56$ & $144 \pm 0.02$ \\
F6 & $3.9 \pm 0.01$ & $0.15 \pm 0.012$ & $99.34 \pm 0.18$ & $12 \pm 0.01$ \\
F7 & $3.8 \pm 0.02$ & $0.14 \pm 0.014$ & $99.56 \pm 0.57$ & $15 \pm 0.02$ \\
F8 & $3.7 \pm 0.04$ & $0.12 \pm 0.013$ & $99.17 \pm 0.11$ & $23 \pm 0.01$ \\
\hline
\end{tabular}

*SD Standard Deviation from the mean, $\mathrm{n}=3$

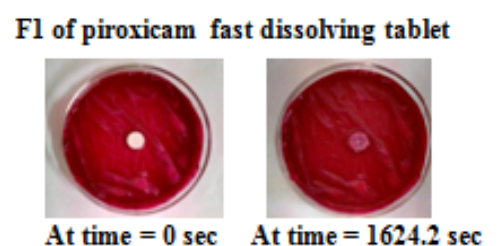

At time $=0 \mathrm{sec}$ At time $=1624.2 \mathrm{sec}$

F3 of piroxicam fast dissolving tablet

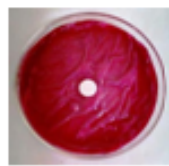

At time $=0 \mathrm{sec}$

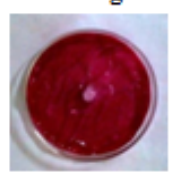

At time $=129 \mathrm{sec}$

F5 of piroxicam fast dissolving tablet

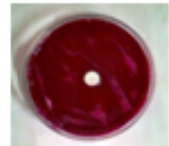

At time $=0 \mathrm{sec}$

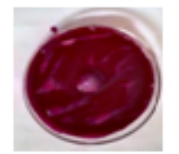

At time $=40 \mathrm{sec}$

F7 of piroxicam fast dissolving tablet
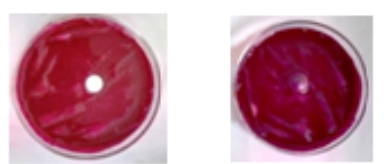

At time $=0 \mathrm{sec}$ At time $=60 \mathrm{sec}$
F2 of piroxicam fast dissolving tablet
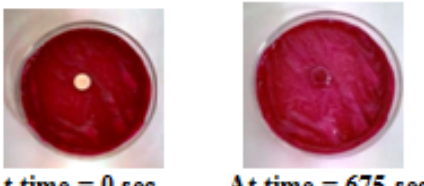

At time $=0 \mathrm{sec}$

At time $=675 \mathrm{sec}$

F4 of piroxicam fast dissolving tablet
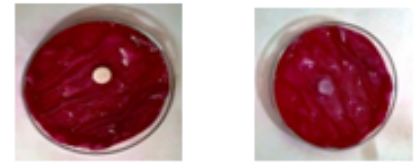

At time $=0 \mathrm{sec} \quad$ At time $=210 \mathrm{sec}$

F6 of piroxicam fast dissolving tablet
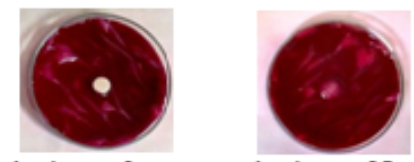

At time $=35 \mathrm{sec}$

F8 of piroxicam fast dissolving tablet
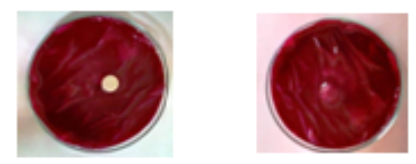

At time $=0 \mathrm{sec}$

Fig. 8: Piroxicam fast dissolving tablets prepared employing starch tartrate involving mannitol as a diluents

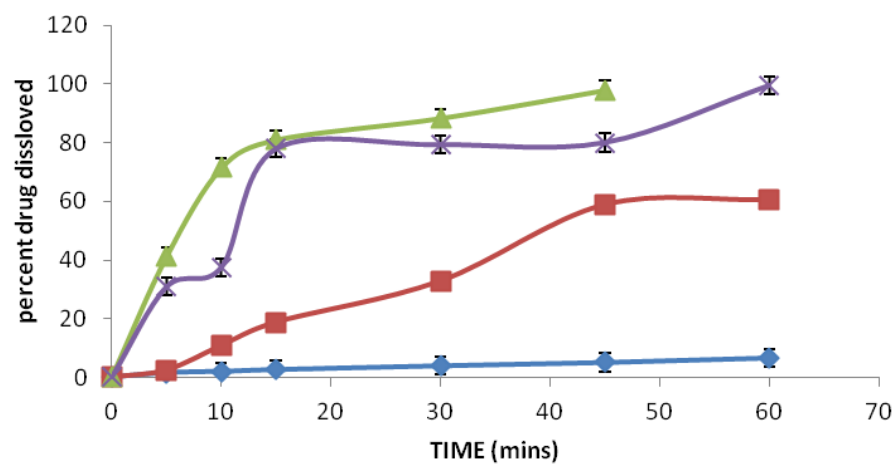

$-\mathrm{F} 1-\mathrm{F} 2-\mathrm{F} 3 \multimap \mathrm{F} 4$

Fig. 9: Dissolution profiles of piroxicam fast dissolving tablets (F1-F4) (n=3, mean \pm SD) 


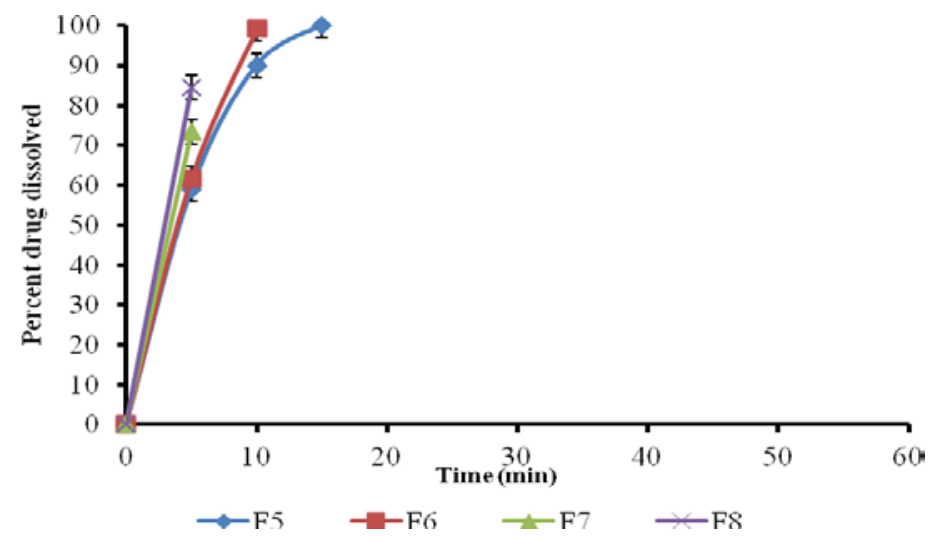

Fig. 10: Dissolution profiles of piroxicam fast dissolving tablets (F5-F8) $(n=3$, mean \pm SD)

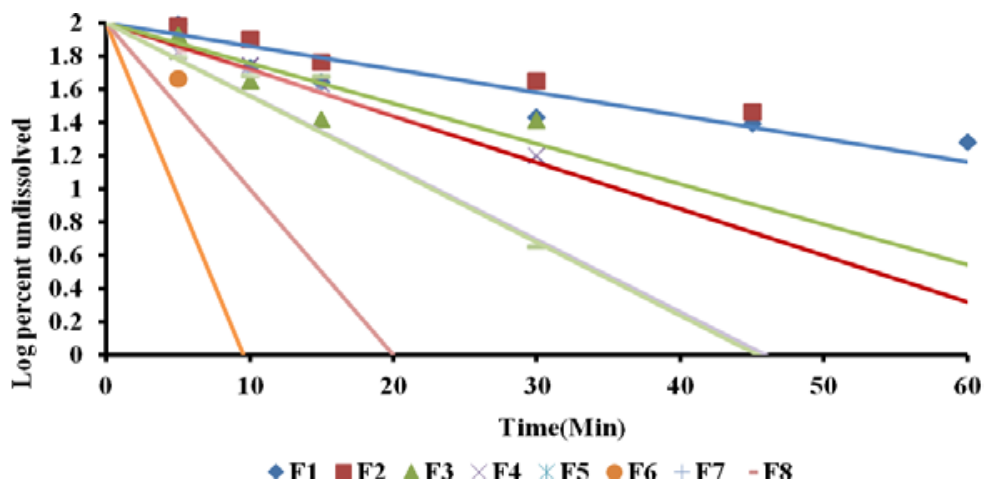

Fig. 10: Time $V_{s}$ Log percent drug undissolved plots for piroxicam fast dissolving tablets (F1-F8) (n=3, mean \pm SD)

Table 4: Piroxicam percent dissolved from fast dissolving tablets employing starch tartrate

\begin{tabular}{|c|c|c|c|c|c|c|c|c|}
\hline Time (min) & F1 & F2 & F3 & F4 & F5 & F6 & F7 & F8 \\
\hline $\mathrm{PD}_{5}$ & $1.61 \pm 0.74$ & $2.44 \pm 0.74$ & $41.23 \pm 0.67$ & $30.82 \pm 0.82$ & $58.83 \pm 0.21$ & $61.66 \pm 0.75$ & $46.89 \pm 0.99$ & $41.24 \pm 0.36$ \\
\hline $\mathrm{DE}_{5} \%$ & $1.1 \pm 0.01$ & $1.3 \pm 0.02$ & $22.8 \pm 0.05$ & $16 \pm 0.02$ & $31.6 \pm 0.01$ & $34.8 \pm 0.05$ & $27.4 \pm 0.02$ & $23.4 \pm 0.03$ \\
\hline $\begin{array}{l}\text { No. of folds } \\
\text { increase in } \\
D_{5} \%\end{array}$ & --- & 1.18 & 20.72 & 14.54 & 28.72 & 31.63 & 24.90 & 21.27 \\
\hline $\mathrm{K}_{1}\left(\mathrm{~min}^{-1}\right)$ & $0.001 \pm 0.001$ & $0.0154 \pm 0.003$ & $0.1123 \pm 0.005$ & $0.0536 \pm 0.002$ & $0.2378 \pm 0.001$ & $0.1842 \pm 0.002$ & $0.1278 \pm 0.002$ & $0.0921 \pm 0.005$ \\
\hline $\begin{array}{l}\text { No. of folds } \\
\text { increase in } \\
\mathrm{K}_{1}\left(\mathrm{~min}^{-1}\right)\end{array}$ & --- & 15.4 & 112.3 & 53.6 & 237.8 & 184.2 & 127.8 & 92.1 \\
\hline
\end{tabular}

*SD Standard Deviation from mean, n=3, PD5-Percent dissolved in 5 min., DE5\%-Dissolution efficiency in 5 min., K1 =First Order Rate Constant

Table 5: ANOVA of disintegration time of piroxicam fast dissolving tablets formulated employing starch tartrate

\begin{tabular}{|c|c|c|c|c|c|}
\hline Source of variation & d. f & S. S & M. S. S ratio & Variance & Result \\
\hline Replicates & 2 & 1764.58 & 882.29 & 0.93 & $\mathrm{P}>0.05$ \\
\hline Treatments & 7 & 53155337.96 & 7593619.70 & 8061.59 & $\mathrm{P}<0.05$ \\
\hline Starch Tartrate (A) & 1 & 6595065.04 & 6595065.04 & 7001.50 & $\mathrm{P}<0.05$ \\
\hline Croscarmellose sodium (B) & 1 & 8107275.04 & 8107275.04 & 8606.90 & $\mathrm{P}<0.05$ \\
\hline Starch Tartratex & 1 & 7044917.04 & 7044917.04 & 7479.07 & $\mathrm{P}<0.05$ \\
\hline Croscarmellose sodium (AB) & & & & & \\
\hline Crospovidone (C) & 1 & 9453915.37 & 9453915.37 & 10036.53 & $\mathrm{P}<0.05$ \\
\hline $\begin{array}{l}\text { Starch Tartratex } \\
\text { Crospovidone(AC) }\end{array}$ & 1 & 6628657.04 & 6628657.04 & 7037.16 & $\mathrm{P}<0.05$ \\
\hline $\begin{array}{l}\text { Crospovidonex } \\
\text { Croscarmellose sodium (BC) }\end{array}$ & 1 & 82837.50 & 82837.50 & 87.94 & $\mathrm{P}<0.05$ \\
\hline $\begin{array}{l}\text { Starch Tartrate } \times \\
\text { Croscarmellose } \\
\text { sodium } \times \text { Crospovidone }(\mathrm{ABC})\end{array}$ & 1 & 7040583.37 & 7040583.37 & 7474.47 & $\mathrm{P}<0.05$ \\
\hline Error & 14 & 13187.42 & 941.95 & -- & -- \\
\hline Total & 23 & -- & -- & -- & -- \\
\hline
\end{tabular}

*SD Standard Deviation from mean, $\mathrm{n}=3, \mathrm{P}<0.05$ indicate significance; $\mathrm{p}>0.05$ indicate non-significance, d. f-Degree of Freedom *S. S-Sum of Square $*$ M. S. S-Mean Sum of Squares, ANOVA= Analysis of Variance. 
Table 5: ANOVA of piroxicam fast dissolving tablets formulated employing starch tartrate

\begin{tabular}{|c|c|c|c|c|c|}
\hline Source of variation & d. $f$ & S. S & M.S.S & Variance & Result \\
\hline \multicolumn{6}{|l|}{ ratio } \\
\hline Replicates & 2 & 319.78 & 159.89 & 2.40 & $\mathrm{P}>0.05$ \\
\hline Treatments & 7 & 17805.68 & 2543.66 & 38.23 & $\mathrm{P}<0.05$ \\
\hline Starch Tartrate (A) & 1 & 345.19 & 345.19 & 5.18 & $\mathrm{P}<0.05$ \\
\hline Croscarmellose sodium (B) & 1 & 326.42 & 326.42 & 4.90 & $\mathrm{P}<0.05$ \\
\hline Starch Tartratex & 1 & 1376.53 & 1376.53 & 20.69 & $\mathrm{P}<0.05$ \\
\hline \multicolumn{6}{|l|}{ Croscarmellose sodium (AB) } \\
\hline Crospovidone (C) & 1 & 7022.97 & 7022.97 & 105.56 & $\mathrm{P}<0.05$ \\
\hline Starch Tartratex & 1 & 42.72 & 42.72 & 0.64 & $P>0.05$ \\
\hline \multicolumn{6}{|l|}{ Crospovidone(AC) } \\
\hline Crospovidonex & 1 & 4177.80 & 4177.80 & 62.79 & $\mathrm{P}<0.05$ \\
\hline \multicolumn{6}{|l|}{ Croscarmellose sodium (BC) } \\
\hline Starch Tartratex & 1 & 139.58 & 139.58 & 2.09 & $\mathrm{P}>0.05$ \\
\hline \multicolumn{6}{|l|}{$\begin{array}{l}\text { Croscarmellose } \\
\text { sodium } \times\end{array}$} \\
\hline \multicolumn{6}{|l|}{ Crospovidone (ABC) } \\
\hline Error & 14 & 931.42 & 66.53 & -- & -- \\
\hline Total & 23 & -- & -- & -- & -- \\
\hline
\end{tabular}

$\mathrm{P}<0.05$ indicate significance; $\mathrm{p}>0.05$ indicate non-significance d. f-Degree of Freedom * S. S-Sum of Square * M. S. S-Mean Sum of Squares

\section{CONCLUSION}

Starch tartrate is an efficient superdisintegrant for fast dissolving tablets. The disintegration and dissolution efficiency in 5 min of the fast dissolving tablets of piroxicam was good and depended on the concentration of superdisintegrant employed i.e., starch tartrate and crospovidone.

The piroxicam drug release from the F6 fast dissolving tablets, employing starch tartrate (5\%) and crospovidone (5\%) by direct compression was $99.32 \% \pm 0.05$ within 10 min. Overall, starch tartrate was found to be a superdisintegrant which enhanced the dissolution efficiency of piroxicam when combined with crospovidone, and hence it could be used in the formulation of fast dissolving tablets to provide immediate release of the contained drug within $10 \mathrm{~min}$.

\section{ABBREVIATION}

FDTs-fast dissolving tablets, FTIR-fourier transform infrared spectra, DSC-differential scanning calorimetry, ANOVA-analysis of variance

\section{AUTHORS CONTRIBUTIONS}

All the author have contributed equally

\section{CONFLICTS OF INTERESTS}

Declared none

\section{REFERENCES}

1. Anupam Roy. Orodispersible tablets: a review. Asian J Pharm 2016;9:19-26

2. Nazia Khanam, Md Irshad Alam, Quazi Md Aamer Iqbal Md Yusuf Ali, Aquil-Ur-Rahman Siddiqui. A review on the optimization of drug delivery system with experimental designs. Int J Appl Pharm 2018;10:7-12.

3. Ashish Masih, Amar Kumar, Shivam Singh, Ajay Kumar Tiwari Fast dissolving tablets: a review. Int J Curr Pharm Res 2017;9:8-18.
4. Aher Smita S, Saudagar RB, Shinde Mayuri S. Review: fast dissolving tablet. Int J Curr Pharm Res 2018;10:5-12.

5. Lachman L, Libermann HA, Kanig JL. The theory and practice of industrial pharmacy. $3^{\text {rd }}$ edition; 1991. p. 233-5.

6. Prashant Bhide, Reeshwa Nachinolkar. Formulation of fastdissolving tablets of doxazosin mesylate drug by direct compression method. Int J Appl Pharm 2017;9:22-8.

7. Syam Prasad Borra, M Chenna Eswaraiah, G Kamalakar Reddy. Formulation development and characterization of meclizine hydrochloride fast dissolving tablets using solid dispersion technique. Int J Appl Pharm 2018;10:141-6.

8. The United States Pharmacopoeia 29, National Formulary 24, Asian Edition. Rockville, MD: United States Pharmacopoeia Convention, Inc; 2006. p. 1890.

9. Ng Raghavendra Rao, Durga Bhavani P. Formulation and evaluation of valsartan fast disintegrating tablets by vacuum drying technique. Asian J Pharm Clin Res 2016;9:73-9.

10. Pratik Swarup Das, Sushma Verma, Puja Saha. Formulation development and evaluation of fast disintegrating tablets of cinitapride hydrogen tartrate by using direct compression technique. Int J Curr Pharm Res 2017;9:93-103.

11. Piyush Jain, RN Gupta, Sandeep Shrivastava. Formulation and evaluation of mouth dissolving tablets of omeprazole. Int J Curr Pharm Res 2016;8:48-51.

12. Rama Rao Tadikonda, Bhaskar Daravath. Formulation and evaluation of meclizine hydrochloride fast dissolving tablets using solid dispersion method. Asian J Pharm Clin Res 2014;7:98-102.

13. Shireen Begum, Syed Abdul, Azeez Basha, Shazia Fatima Formulation and in vitro evaluation of mouth dissolving tablets of amlodipine and rosuvastatin. Int J Curr Pharm Res 2015;7:43-8.

14. Babji Movva, D Laxman Kumar, K Mohan Ravi Kumar. Formulation and evaluation of fast dissolving tablets of ranitidine hydrochloride by hole technology. Asian J Pharm Clin Res 2013;6:143-7.

15. Sachan Anupam K, Tripathi K, Visnoi G, Rasheed A, Sharma R, Gangwar SS. Formulation development and characterization of piroxicam fast dissolving tablets approved for the treatment of arthritis. Int J Drug Dev Res 2015;5:187-91. 